\title{
Local currency systemic risk *
}

\author{
Nicola Borri \\ LUISS
}

This version: September 8, 2017

\begin{abstract}
Emerging country governments increasingly issue local currency denominated bonds and foreign investors have been increasing their holdings of these assets. By issuing debt denominated in local currency, emerging country governments eliminate exchange rate risk. The growing stock of local currency government debt in the financial portfolios of foreign investors increases their diversification and exposure to fast growing economies. In this paper, we highlight some of the risks associated to this recent trend. First, we adopt the $C o V a R$ risk-measure to estimate the vulnerability of individual countries to systemic risk in the market for local currency government debt. Second, we show that our country-level estimates of vulnerability increase with the share of local currency debt held by foreign investors. A version of the old adage "When New York sneezes, London catches a cold," used often to describe the relationship between the stock markets in these two cities, still applies between individual emerging countries and the aggregate market for local currency government debt.
\end{abstract}

Keywords: CoVaR, emerging markets, local currency debt, contagion, systemic risk JEL Classification: C58, F21, F34, G11, G15, G32

*Borri: Department of Economics and Finance, LUISS University, Viale Romania 32, 00197 Rome, Italy; nborri@luiss.it; Tel: +39 06 85225959; http://docenti.luiss.it/borri. I thank Kirill Shakhnov, Federico Nucera and an anonymous referee for helpful discussions and comments. 


\section{Introduction}

Governments in emerging countries increasingly issue bonds denominated in local currency and the share of this market held by foreign investors has been progressively growing. By issuing debt denominated in local currency, governments curb the exposure to exchange rate risk which, instead, is typical of debt denominated in foreign currency (for example, Eichengreen et al. (2003) and Margolin (2007) discuss the risks and costs of issuing debt denominated in foreign currency, mostly the U.S. dollar). By investing in local currency denominated bonds, foreign investors increase the diversification of their financial portfolios and gain exposure to fast growing economies. In this paper, we highlight some of the risks associated to this recent trend. In fact, we show that a country's vulnerability to systemic risk increases with the share of local currency denominated government debt held by foreign investors ${ }^{1}$. In some sense, a version of the old adage "When New York sneezes, London catches a cold", used often to describe the stock markets in these two cities, applies between emerging countries and the aggregate market for local currency denominated government debt.

The stock of debt issued by governments in emerging countries and denominated in local currency increased by a factor of 4 since 2002 and it is currently worth over 4 trillion U.S. dollars. On the contrary, over the same period, the stock of debt denominated in foreign currency was never above the 1 U.S. dollar trillion mark (see figure 1). The growing stock of government debt denominated in local currency shows that emerging countries are breaking free from the so called "original sin" (i.e, the difficulty governments face when borrowing abroad in their own, or local, currency). Foreign investors are also progressively becoming more relevant players in the market for local currency government debt. In the bottom panel of figure 1, we report the foreign holdings of aggregate debt issued by emerging country governments, as a percentage of their aggregate GDP. While the foreign holdings of debt denominated in local currency have been progressively increasing, reaching approximately 3 percent in 2016, the holdings of debt denominated in foreign currency have been declining and were approximately 2 percent in 2016. In this paper, we argue that the increased share of local currency debt held by foreigners is a potential source of transmission of shocks both globally, and across different emerging markets. Intuitively, the larger the share held by foreign investors, the stronger the impact of shocks to their marginal utilities on the price of government bonds denominated in local currency. On the other hand, when foreign

\footnotetext{
${ }^{1}$ The literature has yet to find a consensus definition of "systemic risk". In what follows, we distinguish systemic from systematic or aggregate risk and define systemic risk as a tail-event risk, or the risk of financial instability "so widespread that it impairs the functioning of a financial system to the point where economic growth and welfare suffer materially" (ECB, 2010; Bisias et al., 2012; Billio et al., 2012).
} 
holdings are small, idiosyncratic country-specific shocks are the main source of variability for local currency bond prices. Borri and Verdelhan (2011) consider the market for government debt issued by emerging countries and denominated in foreign currency, traditionally held mostly by foreign investors, and find that global common factors explain a large share of the variability of excess returns. Looking at equity markets, Kaminsky et al. (2004) show that active trading strategies of equity mutual fund investors, like momentum strategies, spread contagion across emerging markets and Beirne et al. (2013) find volatility spillovers from mature to emerging stock markets. On the contrary, the large cross-country differences in the shares of local currency government debt held by foreigners could also generate differences in the transmission of common global shocks across emerging countries ${ }^{2}$. Borri and Shakhnov (2017) describe this intuition more formally in a model with two partially segmented markets for local and foreign currency denominated government debt and show that the larger the share of foreign investors, investing in both markets, the higher the degree of integration across the two markets and globally. To the best of our knowledge, this is the first paper that studies tail-risk contagion in the market for local currency denominated government debt for emerging countries.

In this paper we focus on contagion of tail-events. In particular, we estimate the vulnerability to systemic risk in the market for local currency denominated debt with the reduced-form risk-measure $\mathrm{CoVaR}$, or conditional value-at-risk, first proposed by Adrian and Brunnermeier $(2016)^{3}$. Systemic risk measures the increase in tail comovement that can arise due to the spreading of distress across different financial markets. CoVaR is a measure of risk conditional upon an adverse shock, where risk is the standard value-at-risk (VaR). VaR measures risk in terms of returns at a given probability: for example, a VaR of $-10 \%$ at the $1 \%$ confidence level indicates that there is a probability of $1 \%$ of a return that is lower or equal to $-10 \%$. Adrian and Brunnermeier use CoVaR to estimate the systemic risk of financial institutions using a combination of market and balance sheet data. Fong and Wong (2012) adopt a similar approach to estimate bi-lateral systemic risk in the Eurozone using sovereign CDS data. In this paper, we find that emerging countries differ substantially in terms of their vulnerability to systemic risk in the market for government debt denominated in local currency. We try to explain the determinants of these differences and find that countries with a larger share of local currency debt held by foreign investors are more

\footnotetext{
${ }^{2}$ See table 2 and the discussion in section 2 for stylized facts about foreign holdings of local currency government debt across countries.

${ }^{3}$ There exist several alternative measures of systemic risk. Many of them rely on CDS data. For example, Acharya et al. (2012) focus on high-frequency marginal expected shortfall; Acharya et al. (2017) and Brownlees and Engle (2016) develop SRISK, which measures capital shortfall conditional on market stress; Billio et al. (2012) builds a risk-measure based on Granger causality across institutions.
} 
Figure 1: Aggregate Emerging Countries' Government Debt
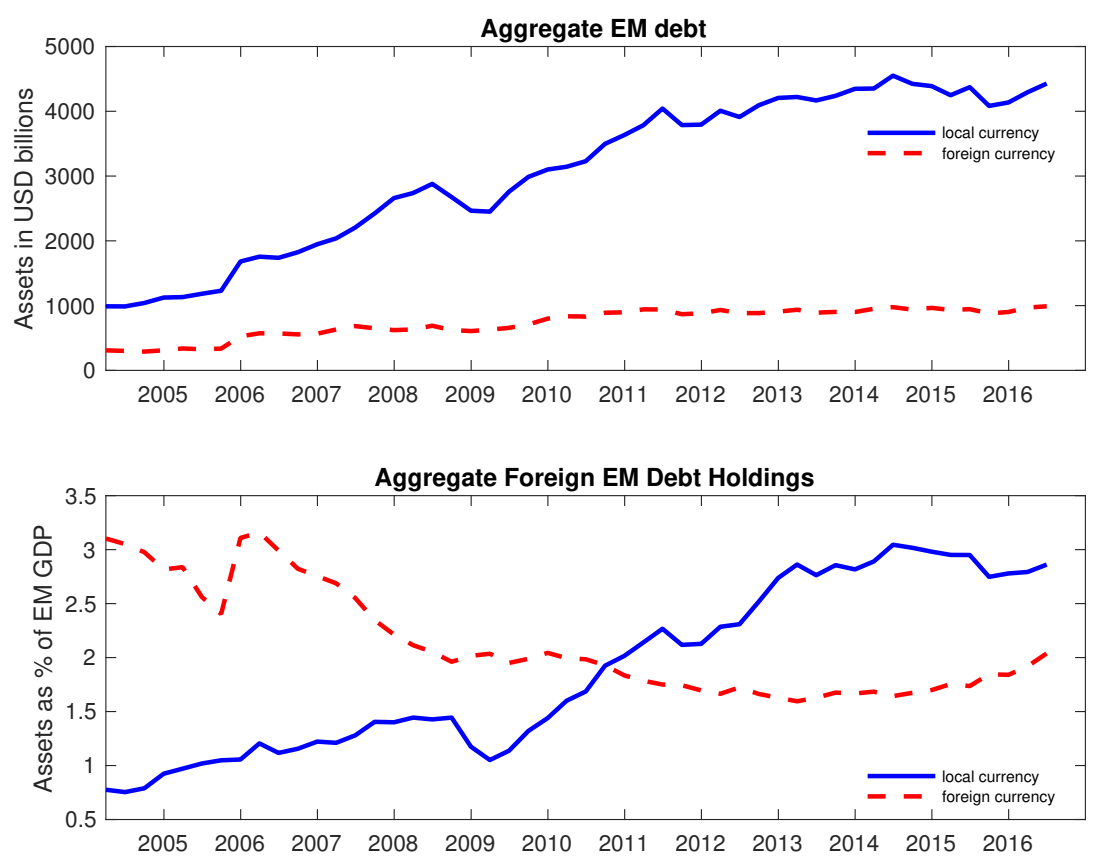

Notes: The top panel of this figure reports aggregate emerging countries' government debt in billions of U.S. dollars. The blue line denotes debt denominated in local currency; the dashed red line debt denominated in foreign currency. Local currency debt is converted in U.S. dollars using the market exchange rate. The bottom panel of this figure reports the aggregate foreign investors holdings of emerging countries' government debt denominated in local currency (blue line) and foreign currency (dashed red line). The aggregate holdings are reported as share of aggregate emerging countries GDP. Data are from Arslanalp and Tsuda (2014) for the period 2002:Q1-2016:Q2 at quarterly frequency.

vulnerable suggesting that increasing integration of capital markets could exacerbate the risk of contagion. These results have important implications for governments and financial institutions both in terms of optimal currency denomination of debt and risk management, and in terms of provisions to curb the volatility of foreign investors' portfolio allocations (see for example Ostry et al. (2012)). In addition, these results are valuable for foreign investors to correctly measure the risk and diversification of their financial portfolios, as also argued by Das and Uppal (2004) for international equity portfolios.

This paper contributes to two strands of the literature. The first studies contagion in emerging markets. Contagion is usually defined as correlation between markets in excess of what would be implied by economic fundamentals (Bekaert and Harvey, 2003a). Most of the research in this strand of the literature has focused on equity markets, and on large financial and economic crises, like the 1994 Mexican and the 1997 Asian crises. Calvo and Mendoza (2000) is a classic model in which globalization may promote contagion by weakening incentives for gathering costly information. Edwards and Susmel (2001) find strong evidence of stock market volatility co-movements across countries. Forbes and Rigobon (2002) argue 
that it is important to correctly account for heteroskedasticity when measuring contagion with correlation coefficients and find that, while there is little evidence of contagion during major financial crises, conversely, there exists a high level of market comovements in normal times. Bekaert and Harvey (2003b) estimate contagion as correlation across residuals of a two-factor model with time-varying betas applied to stock returns in three different regions - Europe, South-East Asia, and Latin America - and find no evidence of contagion from the Mexican crisis, but find evidence of contagion during the Asian crisis. Tai (2007) finds that Asian emerging stock markets become integrated into world capital markets since their official liberalization, and that there is evidence of contagion from stock to foreign exchange markets during the Asian crisis. Dell'Ariccia et al. (2016) study systemic risk for firms in emerging markets that borrow in foreign currency and that have, typically, income in local currency and argue for regulatory measures to limit currency mismatches. The second strand of the literature studies the growing market for local currency sovereign and corporate debt in emerging countries. Peiris (2010) finds that higher foreign participation reduces long-term local currency government bond yields and volatility in a group of 10 emerging countries for the period 2000-2009. Miyajima et al. (2015) argue that local factors, rather than global factors, are the main drivers of local currency bond yields. Du and Schreger (2016) construct a measure of local currency credit spread as the yield difference between the rate on local currency bonds and a synthetic local currency risk-free rate computed using cross-currency swaps. The authors find that the local currency spread is positive, and sizable and, contrary to foreign currency credit spreads, depend more on domestic, than global, conditions and have lower means and cross-country correlations. Hale et al. (2016) look at individual private, rather than sovereign, bonds issued in local currency. Finally, this paper is also related to the recent literature that looks at the fast growing market for European countries' government debt after the introduction of the Euro and at the onset of the European sovereign debt crisis and finds that European-wide common factors became more important after the adoption of the common currency. For example, Ang and Longstaff (2013) find that there is more systematic risk among European debt markets than for U.S. debt markets at the state level. Abad et al. (2010) find that European government bond markets in the period 1999-2008 are only partially integrated and that domestic factors explain bond returns. In addition, they find that non-EMU European countries are more influenced by world risk factors, and less by domestic or EMU-wide factors. Geyer et al. (2004) look at European government bonds in the period 1999-2004 and find that most of the variation in spreads is due to common factors that are linked to European corporate and swap spreads. Pagano and Von Thadden (2004) and Gómez-Puig (2008) find that with the introduction of the Euro, international risk factors became less important while the importance of local factors 
increased ${ }^{4}$.

The remainder of the paper is organized as follows. Section 2 describes the data. Section 3 introduces our conditional measure of vulnerability to systematic risk. Section 4 presents the results of our estimations. Section 5 concludes.

\section{Data}

In this paper we use $C o V a R$ to measure the exposure to systemic risk in the aggregate market for local currency government debt issued by emerging countries. As explained in greater details in section 3, in the estimation of $C o V a R$ we include state variables to capture time-variation in risk exposure to global risk factors. First, we collect daily frequency total return indices of local currency denominated debt issued by emerging governments from J.P. Morgan through Datastream. In particular, we use the J.P. Morgan GBI-EM indices for local currency denominated debt. The JPM GBI-EM indices track local currency bonds issued by emerging market governments and are based on local currency, and not U.S. dollar, values, and include individual bonds that meet specified criteria in terms of liquidity and reliability of market prices. The countries in our sample are Argentina, Brazil, Chile, China, Colombia, Hungary, India, Indonesia, Malaysia, Perù, Philippines, Poland, Romania, Russia, South Africa, and Turkey. The longest sample is 31/12/2002-30/6/2016, but the size of the cross-section progressively increases as more countries enter the indices. In particular, there are 7 countries at the beginning of the sample and 17 at the end. We build daily returns as $\log$ differences in the total return price indices. J.P. Morgan also publishes two additional families of emerging market government bond indices. The classic EMBI indices, formed in the early 1990s after the issuance of the first Brady bonds, collect foreign currency denominated debt (mostly U.S. dollar denominated). The ELMI+ indices also collect local currency denominated debt, but for the money market and therefore have a very short duration (on average, 0.15 years against the average maturity of 5 years at the end of 2015 for the bonds included in the J.P. Morgan GBI-EM indices). In this paper, we focus exclusively on the J.P. Morgan GBI-EM local currency denominated bond indices. For the countries in the sample, we additionally collect exchange rate data with respect to the U.S. dollar from Reuters and Barclays through Datastream (exchange rates are in units of foreign currency per U.S. dollar). In addition, we collect daily frequency total return indices corresponding to variables commonly used to capture global risk factors relevant for emerging countries and that we use in the conditional estimation of $C o V a R$. In particular, we collect data for

\footnotetext{
${ }^{4}$ See also De Grauwe and Ji (2012); Battistini et al. (2013); Black et al. (2016); Reboredo and Ugolini (2015).
} 
the S\&P500 Composite and the CBOE VIX to capture the state of the global economy and investors' risk aversion and sentiment; the Bank of America Merrill Lynch US Corporate Bond Index to capture global default risk; and the Bloomberg Commodity Index to capture the values of a broad basket of commodities, as these are an important source of export revenues for emerging countries. Finally, we collect data on a set of potential determinants of the differences in vulnerability to systemic risk across countries. In particular, we collect quarterly data on the shares of local currency and total government debt held by foreigners, nominal GDP, and shares of local currency and total government debt over GDP from Arslanalp and Tsuda (2014) for the period 2002:Q1-2016:Q2; annual values of the KAOPEN index by Chinn and Ito (2006) measuring a country's degree of capital account openness; sovereign credit ratings on local currency debt from Standard \& Poor's ${ }^{5}$. These variables capture both the size and the risk of the local currency debt markets, as well as how relevant are foreign investors. Section 4 discusses at greater length why these variables are good candidates to explain differences in vulnerability to systemic risk across the countries in our sample.

We report in tables 1 to 3 descriptive statistics of the data. In panel $\mathrm{A}$ and $\mathrm{C}$ of table 1 we report mean, standard deviation, skeweness, minimum and maximum values for the log returns on the local currency bond indices and the state variables used in the conditional estimation of $\triangle \mathrm{CoVaR}$ of section 4 . The mean daily returns in local currency are all positive and range from $0.011 \%$ for Chile to $0.051 \%$ percent for Turkey. Also volatilities and skewness differ substantially across countries: for example, in the period 31/12/2002-30/6/2016, Argentina registered a minimum daily return of $-14 \%$ and a maximum daily return of $10 \%$. Brazil, Indonesia and Russia also experienced large swings in the prices of their local currency government bonds. Since foreign investors buying bonds denominated in local currency also face exchange rate risk unless this is hedged, in the empirical estimation of $\triangle C o V a R$ we convert the returns on the local currency bond indices in U.S. dollars (see section 4). In panel B we report the mean and standard deviation of the daily log changes in the exchange rates with respect to the U.S. dollar. For most countries, the mean exchange rate growth is positive indicating a depreciation of the local currency with respect to the U.S. dollar over the sample considered. Therefore, from the perspective of unhedged foreign investors, the returns on the investment in local currency bonds are reduced once converted back into dollars. In table 2 we report descriptive statistics on the shares of local currency, and total,

\footnotetext{
${ }^{5}$ The Chinn-Ito KAOPEN index is a number in between 0 and 1 and it is equal to 1 for the U.S. For additional details you can refer to Arslanalp and Tsuda (2014) and Chinn and Ito (2006). Standard \& Poor's assigns letter credit ratings on local currency government debt (i.e., AAA corresponds to the highest credit worthiness, and SD to selective default). We convert the letter ratings in a numerical ordering, with a lower number corresponding to a higher credit worthiness.
} 
Table 1: Descriptive Statistics: financial data

\begin{tabular}{lccccccc}
\hline \hline & \multicolumn{1}{c}{ Panel A: local currency returns } & & \multicolumn{3}{c}{ Panel B: exchange rates } \\
\hline & mean (\%) & std.dev (\%) & skew & $\min (\%)$ & max $(\%)$ & mean (\%) & std.dev (\%) \\
\hline Argentina & 0.027 & 1.183 & -1.185 & -14.063 & 10.213 & 0.042 & 0.943 \\
Brazil & 0.048 & 0.316 & -8.546 & -9.626 & 2.174 & -0.003 & 0.924 \\
Chile & 0.011 & 0.124 & -0.127 & -0.799 & 0.987 & -0.002 & 0.620 \\
China & 0.015 & 0.213 & -1.865 & -3.968 & 3.434 & -0.006 & 0.108 \\
Colombia & 0.038 & 0.292 & -0.798 & -2.927 & 2.355 & 0.001 & 0.700 \\
Hungary & 0.030 & 0.407 & -0.983 & -5.218 & 3.737 & 0.007 & 0.984 \\
India & 0.026 & 0.304 & -0.756 & -4.804 & 3.719 & 0.010 & 0.426 \\
Indonesia & 0.048 & 0.692 & -1.007 & -11.121 & 8.912 & 0.011 & 0.486 \\
Malaysia & 0.015 & 0.142 & -0.558 & -1.426 & 1.322 & 0.001 & 0.394 \\
Mexico & 0.034 & 0.325 & 0.518 & -2.563 & 4.061 & 0.016 & 0.717 \\
Peru & 0.027 & 0.423 & 1.973 & -3.209 & 7.012 & -0.002 & 0.295 \\
Philippines & 0.027 & 0.433 & -0.814 & -3.806 & 2.577 & -0.004 & 0.331 \\
Poland & 0.023 & 0.195 & -0.841 & -2.458 & 1.348 & 0.001 & 0.913 \\
Romania & 0.027 & 0.145 & -0.737 & -0.746 & 0.565 & 0.005 & 0.786 \\
Russia & 0.030 & 0.539 & -2.007 & -10.369 & 8.320 & 0.020 & 0.851 \\
South Africa & 0.034 & 0.399 & -1.331 & -6.516 & 2.819 & 0.015 & 1.079 \\
Turkey & 0.051 & 0.372 & -0.496 & -3.196 & 2.591 & 0.016 & 0.825 \\
Mean & 0.030 & 0.372 & -1.151 & -5.107 & 3.891 & 0.008 & 0.825 \\
& Panel C: state variables & & & & & \\
\hline S\&P 500 & 0.032 & 1.186 & -0.318 & -9.460 & 10.958 & & \\
CBOE VIX & -0.016 & 6.725 & 0.729 & -35.059 & 49.601 & & \\
U.S. Corporate & 0.016 & 0.648 & -0.546 & -5.674 & 4.100 & & \\
Commodities & -0.002 & 1.085 & -0.230 & -6.401 & 5.650 & & \\
\hline \hline
\end{tabular}

Notes: This table reports descriptive statistics of the financial data described in section 2. Panel A reports mean, standard deviation, skewness, minimum and maximum for the log returns on local currency government bond indices. Panel B reports mean and standard deviation for the log changes of the exchange rates with respect to the U.S. dollar (exchange rates are expressed in units of local currency per U.S. dollar). Panel C reports mean, standard deviation, skewness, minimum and maximum for the log returns on the state variables used in the conditional estimation of CoVaR described in section 4 . The sample is $31 / 12 / 2002-30 / 6 / 2016$. Data are from Datastream at daily frequency.

government debt held by foreigners, and on the local currency and total government debt over GDP. On average, foreign investors held 15 percent of emerging country governments' debt denominated in local currency, and 30 percent of the total (i.e., local and foreign currency denominated). However, there exist both large differences across countries, and over time within a country. Foreign investors held only a small fraction of the local currency denominated debt issued by China and India ( $0.7 \%$ and $1.4 \%$ on average, respectively). On the contrary, foreign investors held a large fraction of local currency debt issued by countries like Hungary (average 30.2\%, maximum 43.6\%), Perù (average 32.0\%, maximum 56.6\%), Ar- 
gentina (average 10.6\%, maximum 40.3\%), or Indonesia (average 22.8\%, maximum 39.6\%). Note that most of the government debt issued by emerging countries is denominated in local currency. On average, government debt in local currency was about 22 percent of GDP, while the total debt (i.e., local and foreign currency denominated) was only a bit larger and approximately equal to 30 percent. Finally, in table 3 we report additional descriptive statistics for the variables used in the panel estimation of section 4. In particular, we report mean, minimum and maximum value for GDP, converted in U.S. dollar, the Chinn-Ito index and $\mathrm{S} \& \mathrm{P}$ sovereign credit ratings on local currency denominated government debt. In our sample, countries differ in terms of openness and default risk. With respect to openness, Chile, Perù and Romania are the most open countries in the sample, while China, South Africa and India the closest. With respect to default risk, China, Malaysia, Poland and South Africa are the safest countries, while Argentina, Indonesia and Turkey the riskiest.

\section{Model}

In this paper we follow Adrian and Brunnermeier (2016) and estimate CoVaR with quantile regressions (Koenker and Bassett Jr, 1978; Koenker, 2005). This is not the only possible estimation technique. For example, $\mathrm{CoVaR}$ can also be estimated with generalized autoregressive heteroskedasticy $(\mathrm{GARCH})$ models. We leave the interested reader to the detailed discussion in Adrian and Brunnermeier (2016) for further details and proofs. We denote with $r^{i}$ the $\log$ returns on the local currency government bond index of country $i=1, \ldots, N$, and with

$$
r^{m}=\sum_{j=1}^{N} \omega_{j} r^{j}
$$

the log returns on the (value-weighted) aggregate market for local currency government debt issued by emerging countries, where $\omega_{j}$ are weights that sum up to 1 . Define with $V a R_{q}^{m}$ the maximum market return at a confidence level of $1-q$

$$
\operatorname{Pr}\left(r^{m} \leq \operatorname{VaR} R_{q}^{m}\right)=q
$$

Intuitively, $\operatorname{VaR}^{m}$ (i.e., the value-at-risk) corresponds to the maximum return in a bad state of the world, i.e., in a situation of aggregate distress for emerging countries. We define $\operatorname{CoVaR} R_{q}^{i \mid m}$ as the $\operatorname{VaR}$ of country $i$ conditional upon the aggregate market $m$ being in a state of distress (i.e., being at $\operatorname{VaR}_{q}^{m}$ ) 


$$
\operatorname{Pr}\left(r^{i} \leq \operatorname{CoVaR} R_{q}^{i \mid m} \mid r^{m}=\operatorname{VaR}_{q}^{m}\right)=q
$$

In order to estimate the conditional risk we use the following quantile regression

$$
r_{t+1}^{i}=\beta_{0, q}^{i \mid m}+\beta_{1, q}^{i \mid m} r_{t+1}^{m}+\sum_{k=1}^{K} \gamma_{k, q}^{i \mid m} r_{t}^{k}+\epsilon_{t+1}^{i \mid m},
$$

where $r^{k}$ are the lagged returns on a set of common factors that we use as conditioning variables $^{6}$. The coefficient $\beta_{1, q}^{i \mid m}$ measures how vulnerable country $i$ is with respect to a state of distress of the aggregate market for local currency government debt. CoVaR is then obtained as fitted value of the quantile regression (3)

$$
C o V a R_{q}^{i \mid r^{m}=V a R_{q}^{m}}=\hat{\beta}_{0, q}^{i \mid m}+\hat{\beta}_{1, q}^{i \mid m} \operatorname{VaR} R_{q}^{m}+\sum_{k=1}^{K} \hat{\gamma}_{k, q}^{i \mid m} \tilde{r}^{k}
$$

where the values of the common factors $\tilde{r}^{k}$ in (4) are those on the dates when $V a R_{q}^{m}$ is observed $^{7}$. We measure the vulnerability of country $i$ to systemic risk in the local currency government debt market with $\triangle \mathrm{CoV} a R_{q}^{i \mid m}$

$$
\Delta \operatorname{CoVaR} R_{q}^{i \mid m}=\operatorname{CoVaR} R_{q}^{i \mid r^{m}=V a R_{q}^{m}}-\operatorname{CoVaR} R_{q}^{i \mid r^{m}=V a R_{0.5}^{m}} .
$$

$\triangle \mathrm{CoV} a \mathrm{R}$ measures the difference between the $\mathrm{CoV} a \mathrm{R}$ of country $i$ conditional on a state of distress in the aggregate market for local currency government debt and the median state (i.e., $q=0.5 \%$ ). Therefore, the larger (in absolute value) the $\Delta C o V a R$, the higher the vulnerability of country $i$ to systemic risk. In this paper, we use $\Delta C o V a R$ as a measure of vulnerability of individual countries to aggregate tail-risk. On the contrary, Adrian and Brunnermeier (2016) use $\Delta C o V a R$ to measure the systemic risk of individual financial institutions, i.e., the vulnerability of the entire financial market with respect to a state of distress of a single financial institution.

\footnotetext{
${ }^{6}$ In the estimation of the quantile regression (3) for country $i$, we exclude the country's $i$ returns from the computation of the aggregate market return $r^{m}$. In the empirical estimation, the weights $\omega_{j}$ correspond to the relative GDP of country $j$. An alternative is to weigh returns by the relative stock of local currency government debt. Results with these alternative weights are similar to those obtained by GDP-weighting and are available upon request.

${ }^{7}$ Following the definition in equation (1), we estimate $\operatorname{Va} R_{q}^{m}$ as the $q$-quantile of the returns on the aggregate market.
} 


\section{Estimation Results}

We estimate the conditional $\Delta C o V a R_{q}^{i}$ for country $i$ and confidence level $1-q$ at quarterly intervals over 1-year rolling windows of daily returns data. We set the confidence level $1-q$ adopting the standard value $q=1 \%$, while in the appendix we show that results are robust to a higher value of $q=5 \%$. We convert returns on local currency denominated debt in a common currency using the local currency exchange rates with respect to the U.S. dollar ${ }^{8}$. Denote with $r_{t+1}^{i, \star}$ the $\log$ returns on the local currency bond index for country $i$, expressed in local currency, and with $s_{t}^{i}$ the log of the exchange rate expressed in units of country $i$ local currency per U.S. dollar. Then

$$
r_{t+1}^{i}=r_{t+1}^{i, \star}-\Delta s_{t+1}^{i}
$$

where $r^{i}$ are the returns in dollars. As in Adrian and Brunnermeier (2016), we include in the estimation state variables that capture time variation in the conditional moments of asset returns. Including the state variables is important to disentangle the vulnerability of each country with respect to tail-risk in the market for local currency government debt from the more general vulnerability with respect to global factors. The set of state variables includes: the returns on the US equity market, proxied by the S\&P500; the log changes in the CBOE VIX; the returns on a broad US corporate bond index; and the returns on a broad index for the commodity market. Note that the state variables are not aggregate risk factors (in fact, they are lagged), but rather variables that condition the mean and the volatility of the $\triangle \mathrm{CoVaR} R_{q}^{i}$. Figure 2 plots the averages of the quarterly estimates of the $\Delta C o V a R$, while figure 3 the complete time-series. Argentina is the most vulnerable country, with an average $\triangle \mathrm{CoVaR}$ \% of about $-5.7 \%$. This means that, in a situation of particular distress in the aggregate market for local currency government debt, we should expect a maximum return, at the $99 \%$ percent confidence level, on local currency Argentinian bonds, of $-5.7 \%$, after controlling for global state variables. South Africa, Russia, Turkey, Hungary and Brazil have all $\Delta C o V a R_{1 \%}$ smaller than $-4 \%$. On the contrary, China is the less vulnerable country, with a $\triangle \mathrm{CoV} a R_{1 \%}$ larger than $-1 \%$. In table 4 we report the averages of the quarterly estimates from equation (4) together with standard errors computed by bootstrap. Note that even though standard errors are large, the quarterly estimates are mostly negative as can be seen in figure 3. Table 4 also reports the averages of all the estimated coefficients from equation (4). The key parameter is $\beta_{V a R^{m}}^{i \mid m}$ : the larger the value the more vulnerable is a country to

\footnotetext{
${ }^{8}$ In the appendix, we show that our results extend to returns on local currency bonds denominated in local currency, as opposed to the U.S. dollar. Brusa et al. (2014) show evidence that foreign investors are compensated for bearing currency risk when investing in local equity markets.
} 
tail-risk in the aggregate market for local currency government debt.

Figure 2: Quarterly $\Delta C o V a R 1 \%$ (averages)

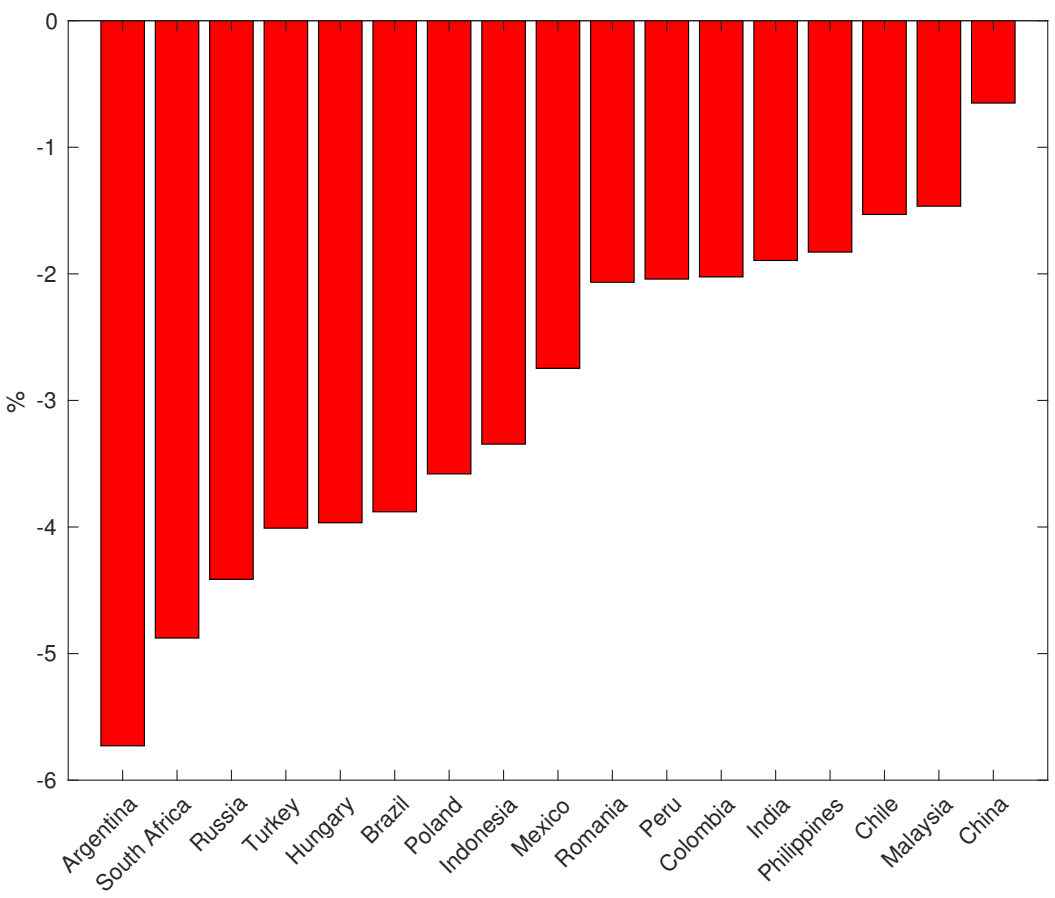

Notes: This figure plots the averages of the quarterly estimates of the $\Delta C o V a R_{1 \%}$ for all the countries in the sample using returns on the local currency bond indices converted in U.S. dollars. Countries are sorted, from left to right, in order of smaller $\Delta C o V a R$. The sample period is 31/12/2003-30/06/2016, or the longest available for countries included in the J.P. Morgan indices at a later date. The $\Delta C o V a R$ are estimated using as conditioning variables the returns on the S\&P500, a U.S. corporate bond index, the CBOE VIX, and a commodity index. Data are from Datastream.

We next use a panel estimation to investigate the determinants of the time-varying country vulnerability to systemic risk in the aggregate local currency government debt market. In particular, we are interested in the relationship between countries' vulnerability, as measured by their quarterly $\triangle \mathrm{CoVaR} R_{q}$, and the quarterly shares of local currency debt held by foreign investors. The assumption we test is whether countries with a larger share of local currency government debt held by foreign investors are more vulnerable, for example because of their common exposure to changes in foreign investors' views and portfolio allocations (for example, Aggarwal et al. (1999); Chari and Kehoe (2003)). The sample period is 2003:Q1-2016:Q3, but the panel is unbalanced as some countries are included in the J.P. Morgan indices at a later date. Results are reported in table 5, where each column corresponds to a different specification of the estimation equation, and standard errors are always robust and clustered at the country level, in order to account for possible auto-correlation and heteroskedasticity of the residuals. In the first column, the only explanatory variables are the foreign holdings of local currency government debt and we include a time fixed effect 
Figure 3: Quarterly $\triangle \mathrm{CoVaR} 1 \%$
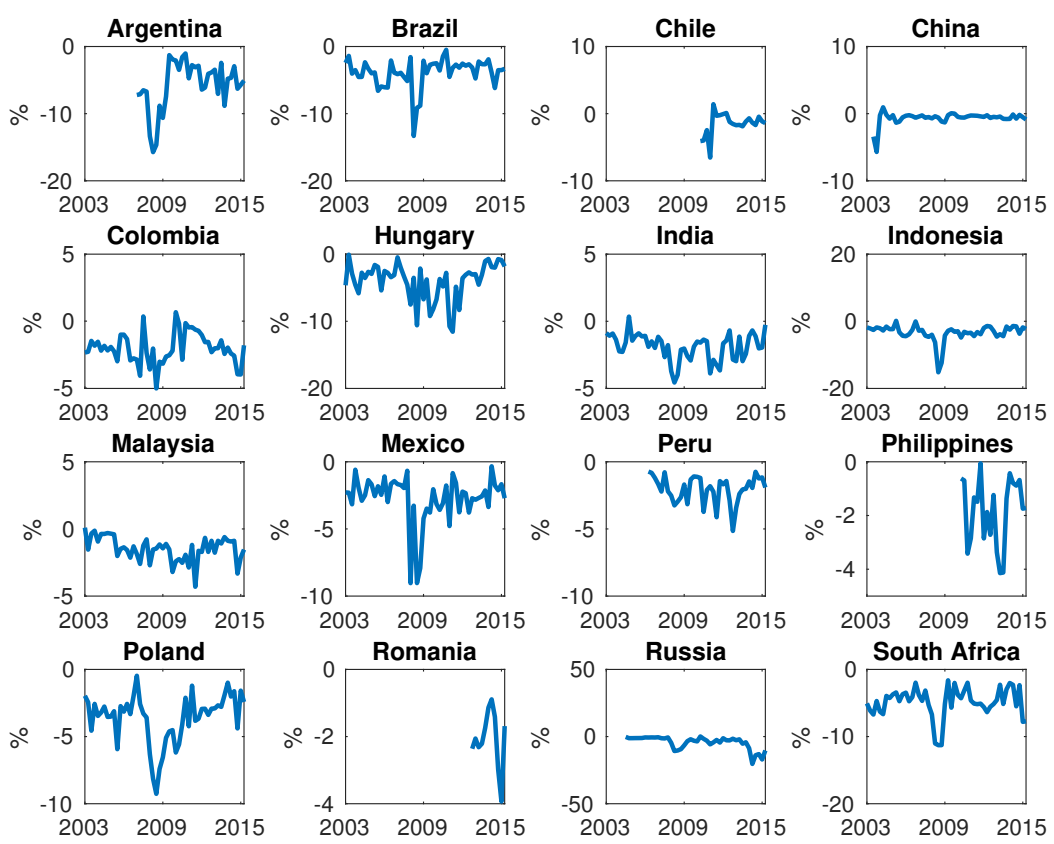

Notes: This figure plots the quarterly estimates of the $\Delta C o V a R_{1 \%}$ for all the countries in the sample using returns on the local currency bond indices converted in U.S. dollars. The sample period is 31/12/2003-30/06/2016, or the longest available for countries included in the J.P. Morgan indices at a later date. The $\Delta C o V a R$ are estimated using as conditioning variables the returns on the S\&P500, a U.S. corporate bond index, the CBOE VIX, and a commodity index. Data are from Datastream.

to control for common factors across countries that changed over time (e.g., changes in financial regulation in developed markets; market entry by new investors like hedge funds; global interest rates; etc.). The estimated coefficient is negative and statically significant at the 1 percent level. Note that the coefficient is also significant from an economic point of view: in fact, a 1 percentage point increase in the share of local currency debt held by foreigners is associated with a decrease in the quarterly $\Delta C o V a R_{q}^{i}$ by approximately 4.4 percentage points. In the second column we add a country fixed effect to account for county-level characteristics that are constant over the sample (e.g., reputation, quality of the institutions, default history, etc.). Including the fixed effects increases the size (in absolute value) of the coefficient attached to the share of local currency debt held by foreigners which is now equal to approximately -6 percent. In columns 4 to 5 we experiment adding additional explanatory variables. We start by including the log of the GDP (to proxy for the size of the economies), the ratios between total and local currency debt and GDP, and the foreign holdings of total government debt. While these coefficients are not statistically significant, our estimate for the impact of the share of local currency government debt held by foreign investors increase in absolute value and remains significant (now at the 10 percent confidence level). We then 
include the Chinn-Ito KAOPEN index, measuring a country's degree of capital account openness. A higher index number corresponds to a more open and integrated economy. Also for this additional variable, the estimated coefficient is not statistically significant with no effect on our dependent variable. In column 5 we include country credit ratings on sovereign debt denominated in local currency by Standard\&Poor's. Credit ratings are supposed to capture the risk of default of an issuer, but are updated infrequently and, therefore, are not suited to explain a high frequency measure of risk. In fact, according to our results, the coefficient on the credit ratings is not statistically significant. In this case, the point estimate for the foreign holdings of local currency debt does not change, but the coefficient is now significant only at the $13 \%$ confidence level. Note how in column 5 the number of observations drops by about 20 percent because of credit ratings data availability. In the separate appendix we show that these results are robust to a higher level for $q=5 \%$, and to using directly returns expressed in local currency, as opposed to converting them into U.S. dollars.

\section{Conclusions}

Emerging countries increasingly issue government bonds denominated in local currency and foreign investors' share of this market has been progressively growing. By issuing debt in local currency, emerging country governments can eliminate exchange rate risk which, instead, is typical of debt denominated in foreign currency. By investing in local currency denominated debt, foreign investors can increase the diversification of their financial portfolios and gain exposure to fast growing economies. However, foreign investors could act as a channel of transmission of shocks, globally and across emerging markets. For example, following an increase in the interest rate in developed markets foreign investors might take their savings out of emerging countries' government debt causing bond prices to drop. In this paper we focus on contagion of tail risk. First, we estimate the vulnerability of emerging countries to systemic risk in the market for local currency government debt using the reducedform risk measure CoVaR developed by Adrian and Brunnermeier (2016). We estimate $C o V a R$ using conditional quantile regressions and controlling for global state variables. We find that countries' vulnerability is time-varying and that there exist large cross-countries differences. Second, we find that the share of local currency debt held by foreign investors positively affects the vulnerability of individual countries to systemic risk in the market for local currency government debt. These results have interesting implications for governments and financial institutions both in terms of optimal currency denomination of debt and risk management, and in terms of provisions to curb the volatility of foreign investors' portfolio allocations, like capital controls or taxes aimed at increasing the cost of sudden capital 
outflows. In addition, these results are important for foreign investors to correctly measure the risk and diversification of their financial portfolios. We leave for future research an in-depth analysis of the policy implications of these results. 


\section{References}

Abad, P., H. Chuliá, And M. Gómez-Puig (2010): "EMU and European government bond market integration," Journal of Banking Eamp; Finance, 34, 2851-2860.

Acharya, V., R. Engle, And M. Richardson (2012): "Capital shortfall: A new approach to ranking and regulating systemic risks," The American Economic Review, 102, $59-64$.

Acharya, V. V., L. H. Pedersen, T. Philippon, and M. Richardson (2017): "Measuring systemic risk," Review of Financial Studies, 30, 2-47.

Adrian, T. And M. K. Brunnermeier (2016): "CoVaR," The American Economic Review, 106, 1705-1741.

Aggarwal, R., C. Inclan, And R. Leal (1999): "Volatility in emerging stock markets," Journal of Financial and Quantitative Analysis, 34, 33-55.

Ang, A. And F. A. Longstaff (2013): "Systemic sovereign credit risk: Lessons from the US and Europe," Journal of Monetary Economics, 60, 493-510.

Arslanalp, S. And T. Tsuda (2014): "Tracking global demand for advanced economy sovereign debt," IMF Economic Review, 62, 430-464.

Battistini, N., M. Pagano, S. Simonelli, Et Al. (2013): "Systemic risk and home bias in the euro area," Tech. rep., Directorate General Economic and Financial Affairs (DG ECFIN), European Commission.

Beirne, J., G. M. Caporale, M. Schulze-Ghattas, and N. Spagnolo (2013): "Volatility spillovers and contagion from mature to emerging stock markets," Review of International Economics, 21, 1060-1075.

Bekaert, G. And C. R. Harvey (2003a): "Emerging markets finance," Journal of Empirical Finance, 10, 3-55.

— (2003b): "Market integration and contagion," Tech. rep., National Bureau of Economic Research.

Billio, M., M. Getmansky, A. W. Lo, And L. Pelizzon (2012): "Econometric measures of connectedness and systemic risk in the finance and insurance sectors," Journal of Financial Economics, 104, 535-559. 
Bisias, D., M. Flood, A. W. Lo, and S. Valavanis (2012): "A survey of systemic risk analytics," Annu. Rev. Financ. Econ., 4, 255-296.

Black, L., R. Correa, X. Huang, and H. Zhou (2016): "The systemic risk of European banks during the financial and sovereign debt crises," Journal of Banking Éamp; Finance, 63, 107-125.

Borri, N. And K. Shakhnov (2017): "Limited participation and local currency sovereign debt," Mimeo.

Borri, N. And A. Verdelhan (2011): "Sovereign risk premia," Mimeo.

Brownlees, C. And R. F. Engle (2016): "SRISK: A conditional capital shortfall measure of systemic risk," Review of Financial Studies.

Brusa, F., T. Ramadorai, and A. Verdelhan (2014): "The international CAPM redux," Mimeo.

Calvo, G. A. and E. G. Mendoza (2000): "Rational contagion and the globalization of securities markets," Journal of International Economics, 51, 79-113.

Chari, V. V. And P. J. Kehoe (2003): "Hot money," Journal of Political Economy, 111, $1262-1292$.

Chinn, M. D. And H. Ito (2006): "What matters for financial development? Capital controls, institutions, and interactions," Journal of development economics, 81, 163-192.

DAs, S. R. AND R. UpPAL (2004): "Systemic risk and international portfolio choice," The Journal of Finance, 59, 2809-2834.

De Grauwe, P. And Y. Ji (2012): "Mispricing of sovereign risk and macroeconomic stability in the eurozone," JCMS: Journal of Common Market Studies, 50, 866-880.

Dell'Ariccia, G., L. Laeven, and R. Marquez (2016): "Financial frictions, foreign currency borrowing, and systemic risk," Mimeo.

Du, W. AND J. Schreger (2016): "Local currency sovereign risk," The Journal of Finance.

ECB (2010): "Financial networks and financial stability," Tech. rep., Financial Stability Review.

Edwards, S. And R. Susmel (2001): "Volatility dependence and contagion in emerging equity markets," Journal of Development Economics, 66, 505-532. 
Eichengreen, B., R. Hausmann, And U. Panizza (2003): "The pain of original sin," Other people's money: Debt denomination and financial instability in emerging market economies, 1-49.

Fong, T. P. W. AND A. Y. WONG (2011): "Analysing interconnectivity among economies," Emerging Markets Review, 12, 432-442.

- (2012): "Gauging potential sovereign risk contagion in Europe," Economics Letters, 115, 496-499.

Forbes, K. J. And R. Rigobon (2002): "No contagion, only interdependence: measuring stock market comovements," The Journal of Finance, 57, 2223-2261.

Geyer, A., S. Kossmeier, And S. Pichler (2004): "Measuring systematic risk in EMU government yield spreads," Review of Finance, 8, 171-197.

Gómez-Puig, M. (2008): "Monetary integration and the cost of borrowing," Journal of International Money and Finance, 27, 455-479.

Hale, G. B., P. Jones, And M. M. Spiegel (2016): "The rise in home currency issuance," Federal Reserve Bank of San Francisco Working Paper, 19.

Kaminsky, G., R. K. Lyons, And S. L. Schmukler (2004): "Managers, investors, and crises: mutual fund strategies in emerging markets," Journal of International Economics, $64,113-134$.

Koenker, R. (2005): Quantile regression, 38, Cambridge university press.

Koenker, R. And G. Bassett JR (1978): "Regression quantiles," Econometrica: journal of the Econometric Society, 33-50.

Margolin, D. (2007): "Financial stability and local currency bond markets," CGFS Papers, 28, 1-142.

Miyajima, K., M. S. Mohanty, and T. Chan (2015): "Emerging market local currency bonds: diversification and stability," Emerging Markets Review, 22, 126-139.

Ostry, J. D., A. R. Ghosh, M. Chamon, and M. S. Qureshi (2012): "Tools for managing financial-stability risks from capital inflows," Journal of International Economics, $88,407-421$.

Pagano, M. And E.-L. Von Thadden (2004): "The European bond markets under EMU," Oxford review of economic policy, 20, 531-554. 
PEIRIS, S. J. (2010): "Foreign participation in emerging markets' local currency bond markets," IMF Working Papers, 1-19.

Reboredo, J. C. And A. Ugolini (2015): "Systemic risk in European sovereign debt markets: A CoVaR-copula approach," Journal of International Money and Finance, 51, $214-244$.

TAI, C.-S. (2007): "Market integration and contagion: Evidence from Asian emerging stock and foreign exchange markets," Emerging Markets Review, 8, 264-283. 


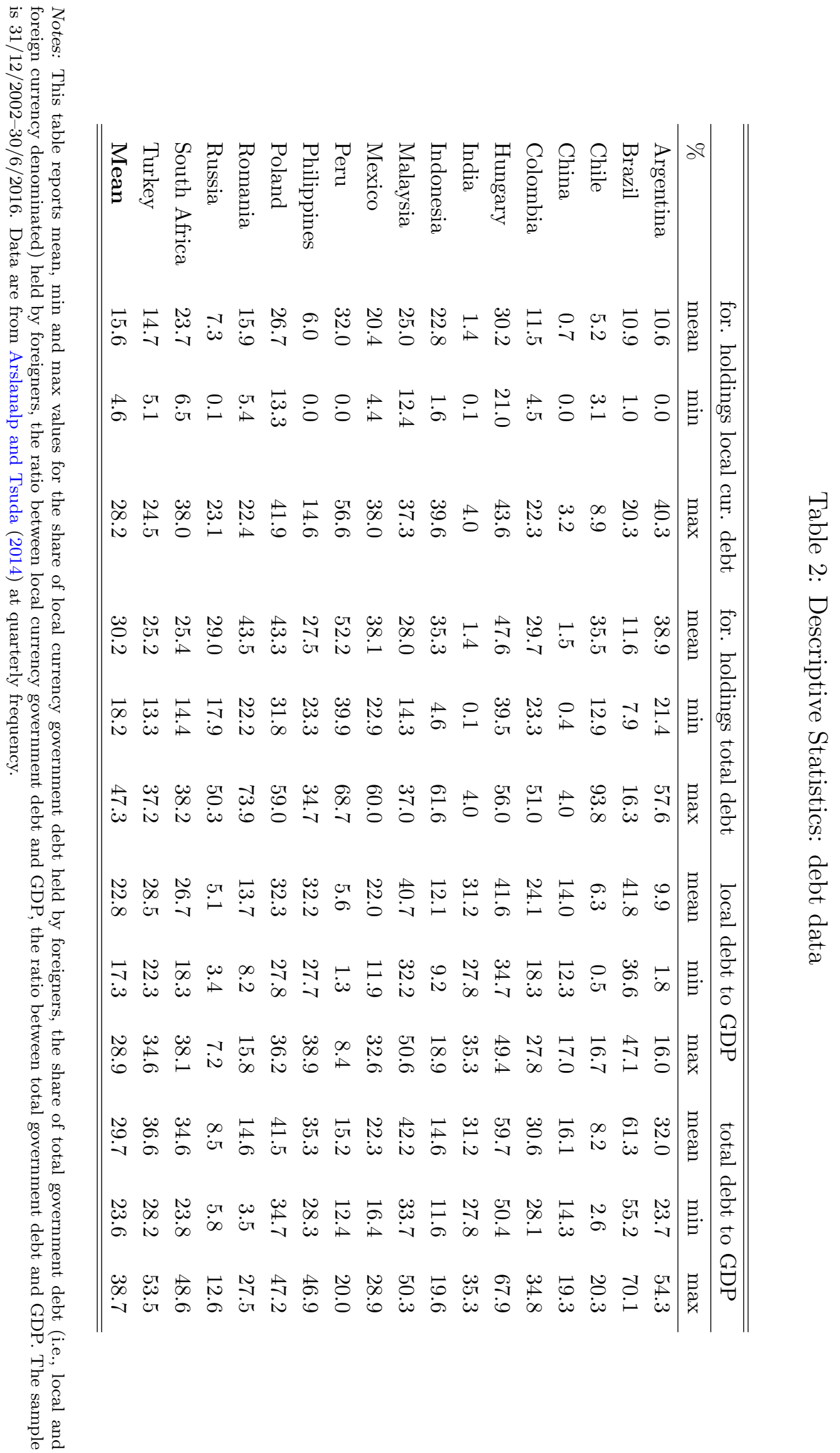


Table 3: Descriptive Statistics: additional macro data

\begin{tabular}{lccccccccc}
\hline \hline & \multicolumn{3}{c}{ GDP (in USD billions) } & \multicolumn{3}{c}{ Chinn-Ito } & \multicolumn{3}{c}{ S\&P Rating } \\
\hline & mean & min & $\max$ & mean & $\min$ & $\max$ & mean & $\min$ & $\max$ \\
\hline Argentina & 373.2 & 154.6 & 585.5 & 0.2 & 0.0 & 0.4 & 16.2 & 14 & 23 \\
Brazil & 1704.7 & 588.8 & 2644.9 & 0.5 & 0.4 & 0.5 & 11.5 & 11 & 13 \\
Chile & 196.2 & 86.5 & 277.2 & 0.9 & 0.7 & 1.0 & 3.0 & 3 & 3 \\
China & 6073.8 & 1717.3 & 10869.0 & 0.2 & 0.2 & 0.2 & 6.8 & 6 & 8 \\
Colombia & 253.4 & 104.5 & 391.6 & 0.4 & 0.2 & 0.7 & 7.9 & 6 & 9 \\
Hungary & 126.8 & 96.5 & 177.5 & 1.0 & 0.8 & 1.0 & 7.4 & 5 & 8 \\
India & 1382.5 & 624.5 & 2056.4 & 0.2 & 0.2 & 0.2 & 10.6 & 9 & 11 \\
Indonesia & 611.4 & 225.2 & 908.4 & 0.6 & 0.4 & 0.7 & 13.2 & 11 & 16 \\
Malaysia & 234.5 & 113.1 & 333.3 & 0.4 & 0.2 & 0.7 & 5.8 & 5 & 6 \\
Mexico & 1054.1 & 746.3 & 1318.2 & 0.7 & 0.4 & 0.7 & 7.1 & 6 & 8 \\
Peru & 137.6 & 60.8 & 201.8 & 1.0 & 1.0 & 1.0 & 10.4 & 10 & 11 \\
Philippines & 191.9 & 82.8 & 294.5 & 0.4 & 0.2 & 0.4 & 9.5 & 8 & 11 \\
Poland & 437.6 & 223.0 & 585.7 & 0.4 & 0.4 & 0.4 & 6.6 & 5 & 7 \\
Romania & 156.6 & 62.2 & 203.4 & 0.9 & 0.4 & 1.0 & 10.5 & 9 & 15 \\
Russia & 1398.3 & 488.8 & 2205.1 & 0.5 & 0.4 & 0.7 & 9.6 & 7 & 15 \\
South Africa & 320.2 & 223.1 & 439.1 & 0.2 & 0.2 & 0.2 & 6.8 & 5 & 8 \\
Turkey & 637.7 & 336.7 & 796.8 & 0.3 & 0.2 & 0.4 & 13.3 & 12 & 16 \\
Mean & 899.4 & 349.1 & 1428.7 & 0.5 & 0.4 & 0.6 & 9.2 & 8 & 11 \\
\hline \hline
\end{tabular}

Notes: This table reports mean, min and max values for GDP (converted in U.S. dollars), the Chinn-Ito KAOPEN index, and the S\&P sovereign credit ratings for local currency debt. The Chinn-Ito KAOPEN index is a number in between 0 and 1 and it is equal to 1 for the U.S. Standard \& Poor's assigns letter credit ratings on local currency government debt (i.e., AAA corresponds to the highest credit worthiness, and SD to selective default). We convert the letter ratings in a numerical ordering, with a lower number corresponding to a higher credit worthiness. The sample is 31/12/2002-30/6/2016, with the exception of the Chinn-Ito index data that ends on 31/12/2014. GDP data are from Arslanalp and Tsuda (2014) at quarterly frequency; the Chinn-Ito index is annual and from Chinn and Ito (2006); S\&P credit ratings are from Datastream. 
Table 4: Coefficient Estimates Quarterly $\Delta C o V a R 1 \%$

\begin{tabular}{|c|c|c|c|c|c|c|}
\hline & $\Delta \mathrm{CoVaR} R_{1 \%}$ & $\beta_{V a R^{m}}^{i \mid m}$ & $\begin{array}{l}\gamma_{S \& P 500}^{i \mid m} \\
\end{array}$ & $\gamma_{V I X}^{i \mid m}$ & $\begin{array}{l}\gamma_{C O R P}^{i \mid m} \\
\end{array}$ & $\begin{array}{l}\gamma_{C O M M}^{i \mid m} \\
\end{array}$ \\
\hline \multirow[t]{2}{*}{ Argentina } & -0.057 & 15.792 & 0.406 & 0.092 & 0.006 & 0.171 \\
\hline & [ 0.036 ] & [ 9.873 ] & [ 0.606 ] & [ 0.097 ] & {$[0.481$ ] } & [ 0.380 ] \\
\hline \multirow[t]{2}{*}{ Brazil } & -0.039 & 8.021 & 0.251 & 0.011 & -0.085 & 0.021 \\
\hline & {$[0.022]$} & [ 5.932 ] & [ 0.376 ] & [ 0.051 ] & {$[0.248$ ] } & [ 0.176 ] \\
\hline \multirow[t]{2}{*}{ Chile } & -0.015 & 2.523 & 0.202 & 0.020 & 0.152 & 0.233 \\
\hline & [ 0.016 ] & [ 2.161 ] & [ 0.146 ] & [ 0.025 ] & [ 0.112 ] & [ 0.103 ] \\
\hline \multirow{2}{*}{ China } & -0.007 & -0.097 & 0.122 & 0.020 & -0.014 & 0.017 \\
\hline & [ 0.009 ] & [ 1.440 ] & [ 0.245 ] & [ 0.036 ] & [ 0.155 ] & [ 0.112 ] \\
\hline \multirow[t]{2}{*}{ Colombia } & -0.020 & 2.524 & 0.078 & -0.018 & 0.097 & 0.163 \\
\hline & {$[0.011]$} & [ 1.987 ] & {$[0.246]$} & [ 0.031 ] & [ 0.147 ] & [ 0.088 ] \\
\hline \multirow[t]{2}{*}{ Hungary } & -0.040 & 10.441 & 0.026 & -0.025 & -0.078 & 0.078 \\
\hline & {$[0.026]$} & [2.025 ] & [ 0.255 ] & [ 0.052 ] & {$[0.234$ ] } & [ 0.142 ] \\
\hline \multirow[t]{2}{*}{ India } & -0.019 & 3.254 & 0.082 & -0.008 & -0.080 & -0.036 \\
\hline & [ 0.010 ] & [ 1.255 ] & [ 0.219 ] & [ 0.030 ] & $0.107]$ & [ 0.140 ] \\
\hline \multirow[t]{2}{*}{ Indonesia } & -0.033 & 7.130 & 0.206 & 0.024 & 0.217 & 0.107 \\
\hline & {$[0.023]$} & [ 1.814 ] & [ 0.291 ] & {$[0.060$ ] } & {$[0.224]$} & [ 0.137 ] \\
\hline \multirow[t]{2}{*}{ Malaysia } & -0.015 & 2.789 & 0.056 & -0.009 & 0.018 & 0.042 \\
\hline & [ 0.009 ] & [ 0.836 ] & [ 0.160 ] & [ 0.016 ] & $0.108]$ & [ 0.066 ] \\
\hline \multirow[t]{2}{*}{ Mexico } & -0.027 & 6.651 & -0.136 & -0.040 & 0.014 & -0.050 \\
\hline & [ 0.018 ] & [ 2.073 ] & [ 0.404 ] & [ 0.043 ] & {$[0.311]$} & [ 0.180 ] \\
\hline \multirow[t]{2}{*}{ Peru } & -0.020 & 4.721 & 0.044 & -0.011 & 0.045 & -0.024 \\
\hline & {$[0.010]$} & [ 1.194 ] & [ 0.186 ] & {$[0.030$ ] } & {$[0.100$ ] } & [ 0.112 ] \\
\hline \multirow[t]{2}{*}{ Philippines } & -0.018 & 4.522 & -0.112 & -0.030 & 0.203 & 0.052 \\
\hline & {$[0.012$ ] } & [ 1.694 ] & [ 0.282 ] & [ 0.023 ] & {$[0.084]$} & [ 0.190 ] \\
\hline \multirow[t]{2}{*}{ Poland } & -0.036 & 10.913 & -0.104 & -0.012 & 0.043 & 0.028 \\
\hline & {$[0.018$ ] } & [ 1.078 ] & [ 0.209 ] & [ 0.032 ] & {$[0.113]$} & [ 0.088 ] \\
\hline \multirow[t]{2}{*}{ Romania } & -0.021 & 4.372 & 0.046 & -0.003 & 0.120 & 0.110 \\
\hline & {$[0.008]$} & {$[0.230$ ] } & {$[0.237$ ] } & {$[0.025$ ] } & {$[0.138]$} & [ 0.062 ] \\
\hline \multirow[t]{2}{*}{ Russia } & -0.044 & 9.736 & 0.303 & 0.015 & 0.148 & 0.127 \\
\hline & {$[0.046$ ] } & [ 6.756 ] & [ 0.998 ] & {$[0.110$ ] } & {$[0.898]$} & [ 0.563 ] \\
\hline \multirow[t]{2}{*}{ South Africa } & -0.049 & 10.959 & -0.138 & -0.034 & 0.082 & 0.007 \\
\hline & [ 0.022$]$ & [ 3.084 ] & [ 0.396 ] & [ 0.042$]$ & [ 0.190 ] & [ 0.139 ] \\
\hline \multirow[t]{2}{*}{ Turkey } & -0.040 & 27.355 & -0.074 & -0.025 & -0.080 & -0.020 \\
\hline & {$[0.016]$} & [ 4.258 ] & {$[0.364]$} & {$[0.038]$} & {$[0.203]$} & {$[0.171]$} \\
\hline
\end{tabular}

Notes: In this table we report the averages of the quarterly estimates of the coefficients from the conditional quantile regressions used to estimate the $\Delta \mathrm{CoVaR} R_{1 \%}$. The quarterly estimates are based on a 1-year rolling window of daily log returns on local currency bond returns. The first sample period is $31 / 12 / 2003-30 / 6 / 2016$. The $\Delta C o V a R_{1 \%}$ are estimated using as conditioning variables the log returns on the following indices: the S\&P500, a U.S. corporate bond index, the CBOE VIX, and a commodity index. In brackets we report bootstrap standard errors. Data are from Datastream. 


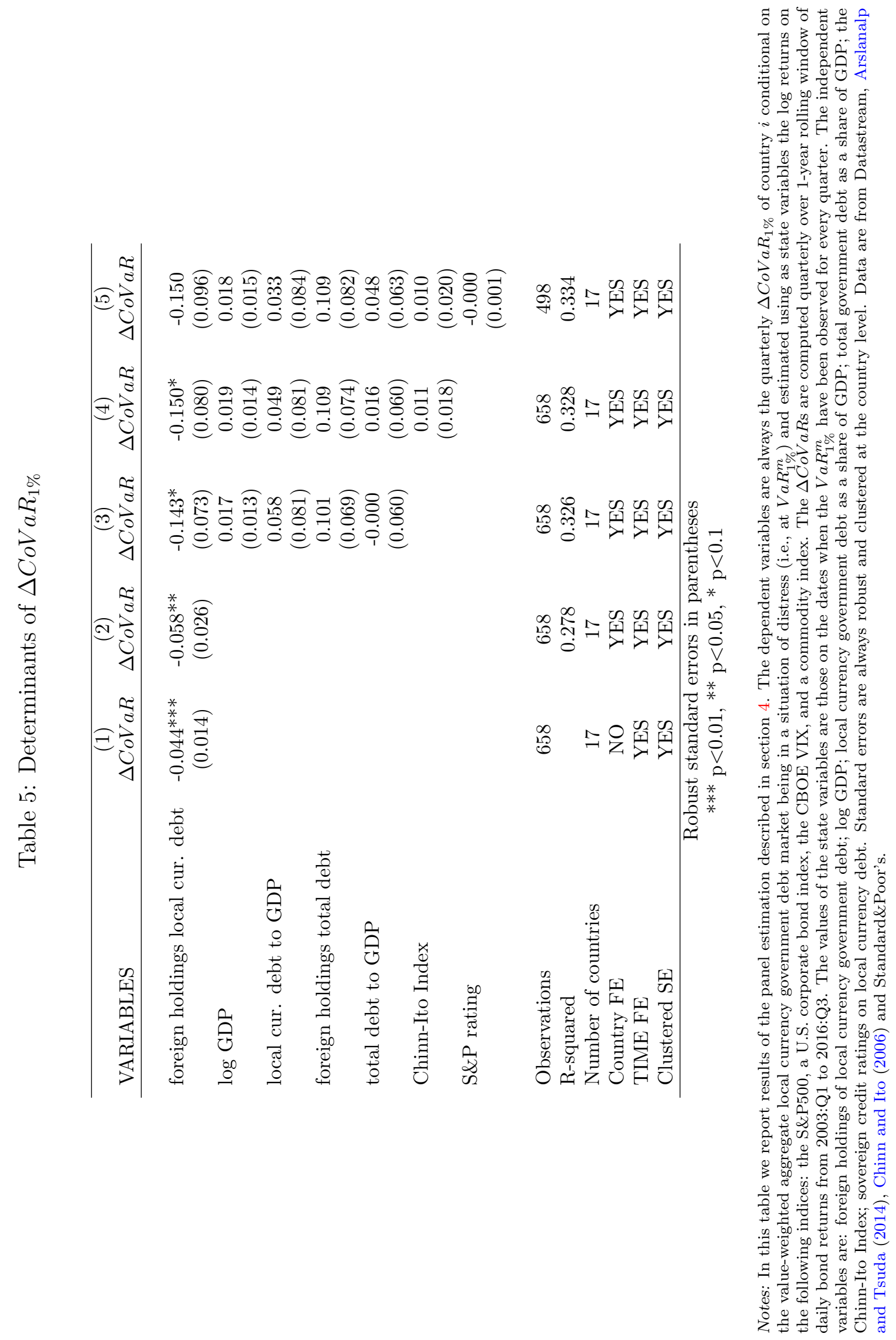


Appendix 


\section{A Estimation of $\triangle \mathrm{CoVaR}$}

In order to estimate the conditional $\Delta \mathrm{CoVaR}$ we follow the algorithm described in Fong and Wong $(2012,2011)$, which is itself based on the general model in Adrian and Brunnermeier (2016). We use the quantreg Matlab function written by Aslak Grinsted (2008) for the quantile regression estimation. First, we convert local currency log returns in U.S. dollars. Second, every quarter starting with 2003:Q1 and ending om 2016:Q3, we estimate $\Delta C o V a R_{q}$ over a 1-year rolling window of daily past log returns. When, for a given country and window, we have missing values for the returns on the local currency bond index, we follow the rule of estimating the $\Delta C o V a R_{q}$ only if at least $1 / 3$ of the observations in the window are available. We construct returns on the aggregate market for local currency bonds as a weighted average of country-level returns, where the weights are obtained by dividing the country-GDP (converted in U.S. dollars) by the aggregate GDP of the countries in the sample (converted in U.S. dollars). By construction, the weights sum up to 1. Results are robust to using weights based on relative stock of local currency debt (converted in U.S. dollars). The conditional variables are lagged by one period.

\section{B Robustness Checks}

In this section we show several robustness checks with respect to the results presented in section 4. First, we repeat the estimation of the conditional $\Delta C o V a R_{1 \%}$ using returns expressed in local currency, as opposed to local currency returns converted in U.S. dollars. Second, we check whether results are robust to a higher value for $q=5 \%$.

\section{B.I Panel Estimation with Returns in Local Currency}

We repeat the estimation of $\Delta C o V a R_{1 \%}$ described in section 4 using log returns expressed in local currency (i.e., $r^{i, \star}$ from equation (6)). Figure A1 plots the time series of the quarterly estimates for $\Delta \mathrm{CoVaR}$ \% for the countries in the sample. We report the results of the panel estimation in table A1. Results are similar to those of table 5, with the main difference being the magnitude of the coefficient attached to the foreign holdings of local currency debt which is now smaller (in absolute value). Also in this case, all the other variables are not statistically significant at conventional confidence levels.

\section{B.II Panel Estimation with $q=5 \%$}

We repeat the estimation of $\Delta C o V a R_{q}$ described in section 4 using a higher value of $q=5 \%$. Also in this case, the coefficient attached to the foreign holdings of local currency government debt is negative and significant at the 15 percent confidence level. 


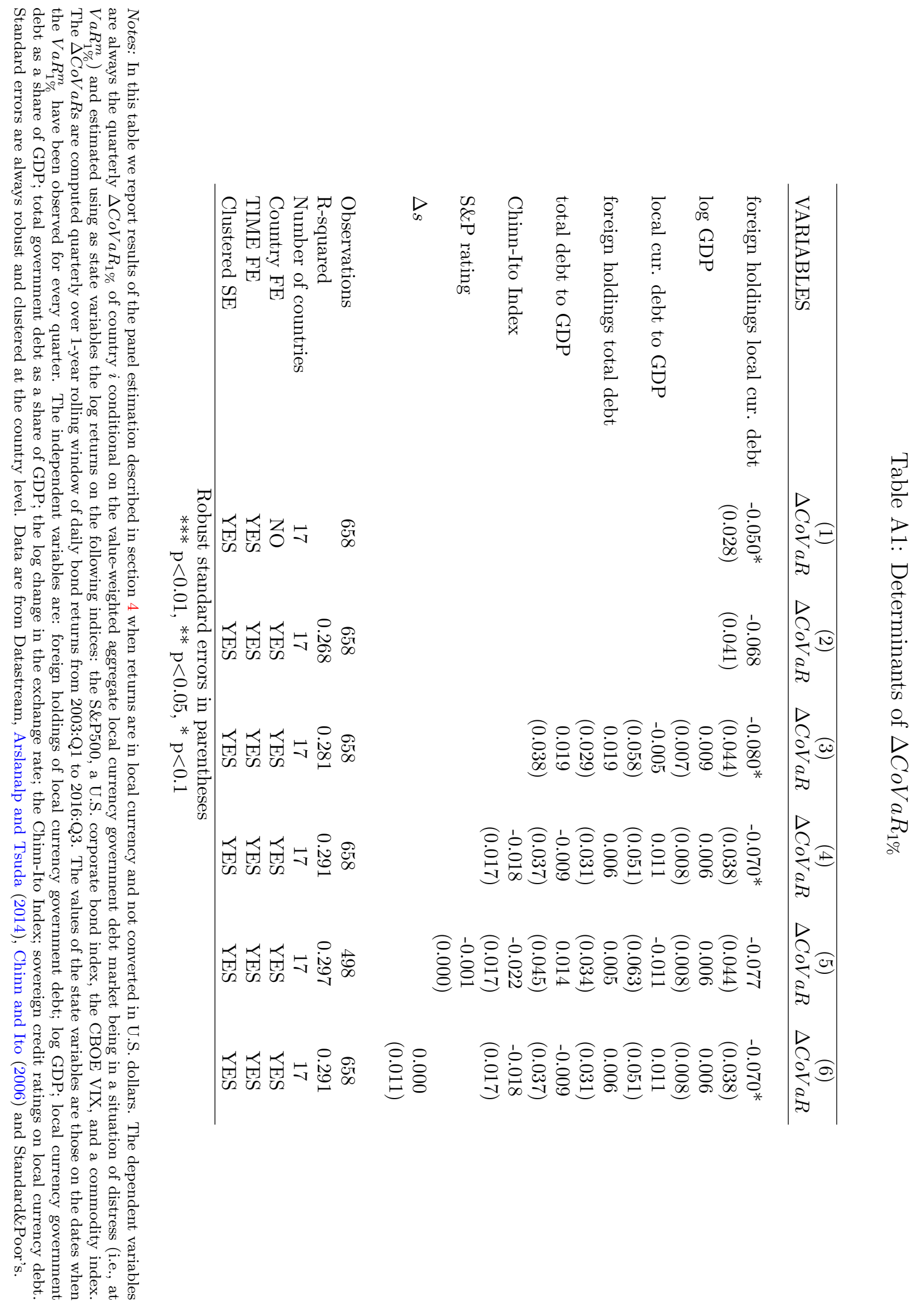




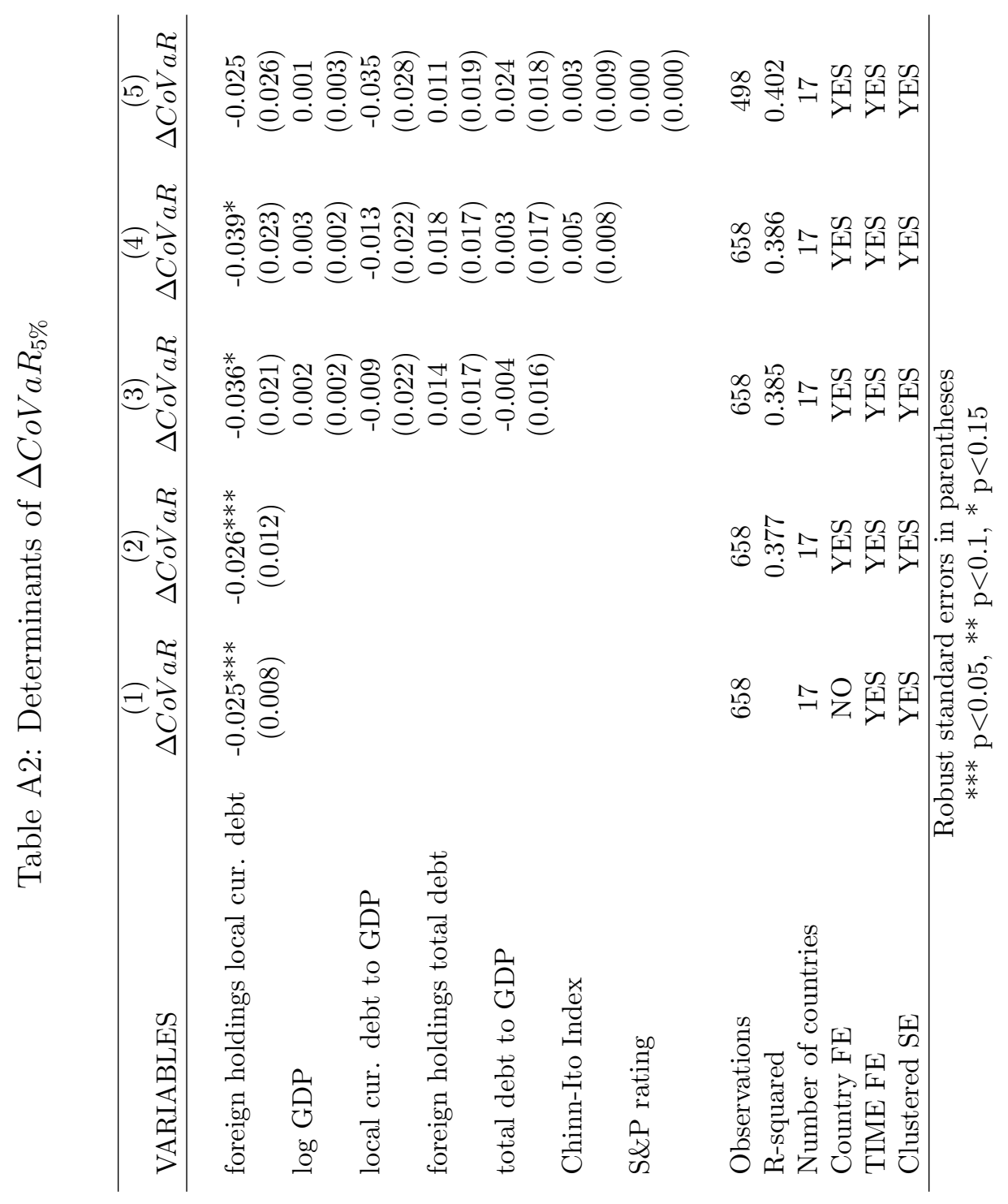

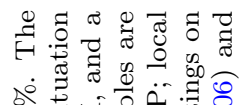

si

\|ा

or. $\exists$ 되

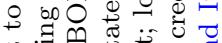

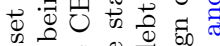

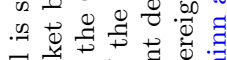

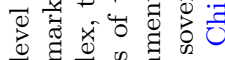

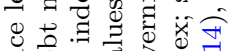

过

녕

of

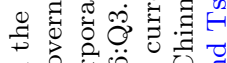

๑ 0 :

ब

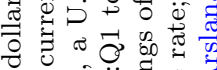

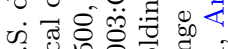

$\checkmark$ 两

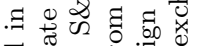

ब.

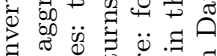

ठํ.

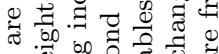

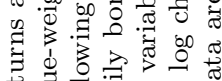

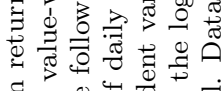

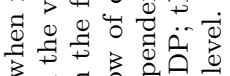

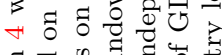

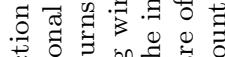

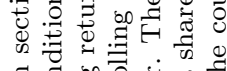

$\exists={ }_{0}^{00}=\dot{0} \omega$

可.

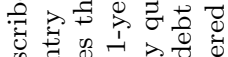

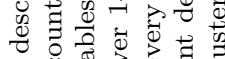

웅

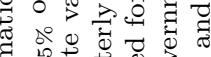

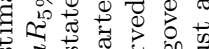

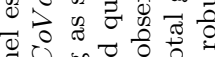

สี 4.9000

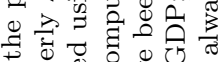

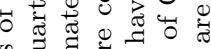

कै

ज़

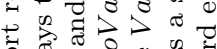

类

สี हैं

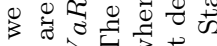

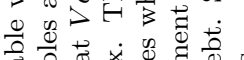

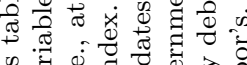

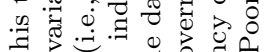

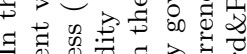

is

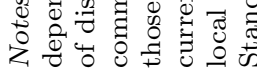


Figure A1: $\triangle$ CoVaR 1\%
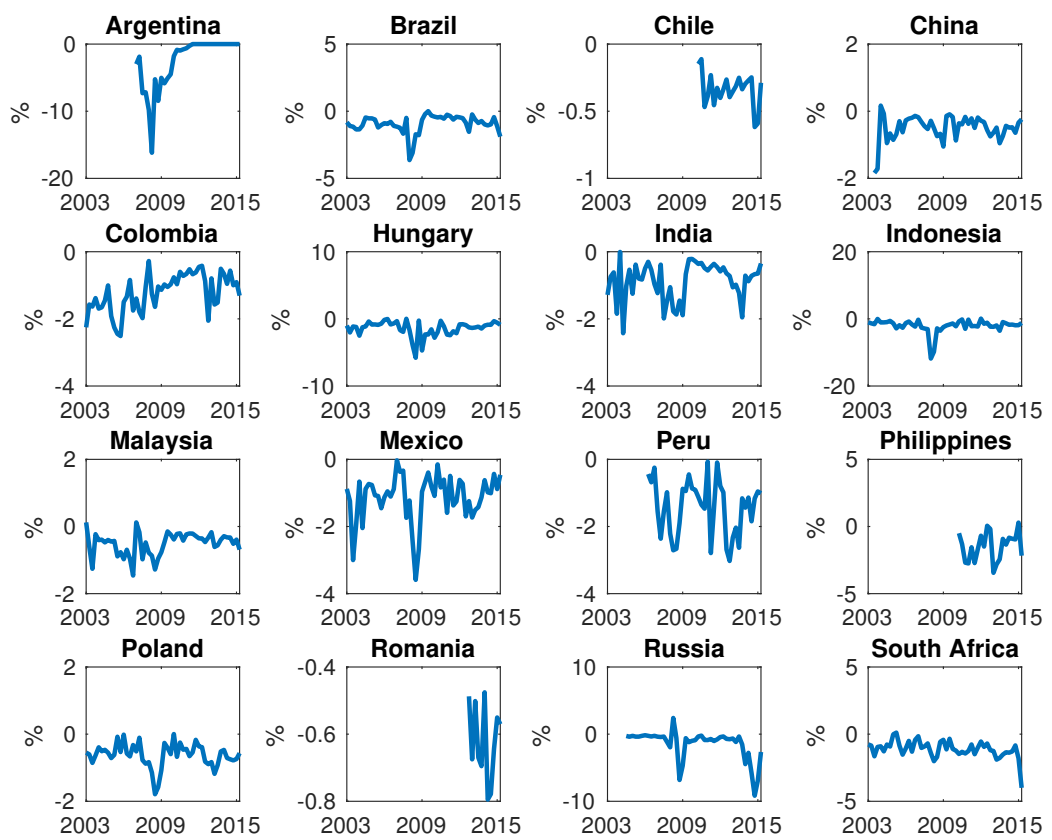

Notes: This figure plots the quarterly estimates of the $\Delta C o V a R_{1 \%}$ for all the countries in the sample using directly the returns on the local currency bond indices expressed in local currency. The sample period is 31/12/2003-30/06/2016, or the longest available for countries included in the J.P. Morgan indices at a later date. The $\triangle C o V a R$ are estimated using as conditioning variables the returns on the S\&P500, a U.S. corporate bond index, the CBOE VIX, and a commodity index. Data are from Datastream. 